Presentation

\title{
Social and environmental conflicts or sustainable development? \\ Positive alarmism
}

\author{
Conflitos socioambientais ou desenvolvimento sustentável? \\ Alarmismo positivo
}

¿Conflictos socioambientales o desarrollo sostenible?

Alarma positiva

(D) Marek Hrubec ${ }^{1}$

\begin{abstract}
The article deals with the topic of mutually interlinked social and environmental conflicts and their possible resolution. First, it articulates the main ideas of the problematic historical dialectic of Western civilization. Second, it focuses on the whole human civilization as well. The sceptical explanatory critique of the historical and current development of the civilization(s) can be a contribution to, first, a positive alarmism which, second, can be reformulated by more developed and sophisticated contemporary analyses. Third, the article analyses a necessary transition from a monological paradigm to an intersubjective paradigm of relations among human beings and the nature in the contemporary context of global capitalism in order to overcome the problematic dialectic of the civilization(s).
\end{abstract}

Keywords: Environment. Ecological conflict. Social conflict. Alarmism. Global capitalism.

Resumo: O artigo trata do tema dos conflitos sociais e ambientais interligados entre si e de sua possível resolução. Em primeiro lugar, articula as principais ideias da problemática dialética histórica da civilização ocidental. Em segundo lugar, enfoca toda a civilização humana também. A crítica explicativa cética do desenvolvimento histórico e atual da(s) civilização(ões) pode ser uma contribuição para, em primeiro lugar, um alarmismo positivo que, segundo, pode ser reformulado por análises contemporâneas mais desenvolvidas e sofisticadas. Terceiro, o artigo analisa a necessária transição de um paradigma monológico para um paradigma intersubjetivo de relações entre seres humanos e a natureza no contexto contemporâneo do capitalismo global para superar a problemática dialética da(s) civilização(ões).

Palavras-chave: Ambiente. Conflito ecológico. Conflito social. Alarmismo. Capitalismo global.

\footnotetext{
${ }^{1}$ Centre of Global Studies, Institute of Philosophy of the Czech Academy of Sciences (Prague, Czech Republic).

author.biographical_data
}

Civitas, Porto Alegre, v. 19, n. 2, p. 281-295, May-Aug. 2019

Este artigo está licenciado sob forma de uma licença Creative Commons Atribuição 4.0 Internacional, que permite uso irrestrito, distribuição e reprodução em qualquer meio, desde que a publicação original seja corretamente citada. https://creativecommons.org/licenses/by/4.0/deed.pt BR 
Resumen: El artículo trata el tema de los conflictos sociales y ambientales mutuamente vinculados y su posible resolución. Primero, articula las ideas principales de la problemática dialéctica histórica de la civilización occidental. Segundo, enfoca también en toda la civilización humana. La crítica escéptica explicativa del desarrollo histórico y actual de la(s) civilización(es) puede ser una contribución para, en primer lugar, un alarmismo positivo que, en segundo lugar, puede ser reformulado por análisis contemporáneos más desarrollados y sofisticados. Tercero, el artículo analiza la transición necesaria de un paradigma monológico a un paradigma intersubjetivo de las relaciones entre los seres humanos y la naturaleza en el contexto contemporáneo del capitalismo global para superar la problemática dialéctica de la(s) civilización(es).

Palabras-clave: Medio ambiente. Conflicto ecológico. Conflicto social. Alarmismo. Capitalismo global.

$\mathrm{W}$

hile social and environmental conflicts are in practice interlinked, analyses of them are usually separated in theory. The reason is complicated and often hidden in the characteristics of the interconnections. Critical analyses of problematic interconnections between processes in societies and environmental contexts are the first step in addressing social and ecological conflicts and risks. It reflects the fact that modern societies created both development as well as destruction, which requires detailed explanatory and descriptive analyses as the second step. The third one follows as proposals for possible solutions of problems by identifying and developing the positive normative fragments of reality, particularly by means of social and environmentally sustainable approaches.

There are already relevant impulses for identification of the problems and partial improvement in practice even if these impulses mainly address intermediate superficial connections between environmental consequences and their causes in a technocratic way, and do not analyse the main causes deeply rooted in societies and in human civilization in general. However, we can appreciate at least the initial attempts to improve the situation. Especially since the foundation of the Club of Rome in 1968 and publication of its first report The limits to growth (1972), various initiatives with a public influence were organized. To mention a few in the last decade, the global community was motivated to take environmental and social development goals more seriously by the conference on sustainable development which was held by the United Nations in Rio de Janeiro in 2012, for example. "The sustainable development goals", so-called Transforming our World: the 2030 Agenda for Sustainable Development (2012), were adopted and then discussed. Some parts have already been implemented by UN member states. It is relevant to analyse critically the 
partial implementation of these obligations in societies and the environment and reflect on the ongoing social and environmental conflicts and potential collapse.

The United Nations Framework Convention on Climate Change adopted the Paris Agreement through 195 states in 2015; this included the aim of pursuing a global approach to the threat of climate change. Specifically, "The Paris Agreement's central aim is to strengthen the global response to the threat of climate change by keeping a global temperature rise this century well below 2 degrees Celsius above pre-industrial levels and to pursue efforts to limit the temperature increase even further to 1.5 degrees Celsius" (United Nations, 2015). The presupposition was that such a transformation would let societies develop without dramatic negative changes.

In 2018, however, the Intergovernmental Panel on Climate Change (IPCC) Special Report on Global Warming stressed that global climate change would be a much bigger problem than was expected. ${ }^{1}$ The IPCC referred that humanity should react before 2030, otherwise dramatic changes were expected, flooding of vast territories, for example. Furthermore the World Wildlife Fund warned in its report: "The astonishing decline in wildlife populations shown by the latest Living Planet Index - a $60 \%$ fall in just over 40 years - is a grim reminder and perhaps the ultimate indicator of the pressure we exert on the planet" (Lambertini, 2018, p. 4). Thus, urgent revolutionary transformation of societies is necessary.

The mentioned UN reports, and some related reports as well, are public documents based on a combination of scientific analyses and a positive cultivated kind of the alarmist formulations which are needed in a situation when corporations and the public spheres, including governments, in all societies, have failed to respond adequately in recent decades. We may ask what is behind the UN alarmism in the positive sense which wants to avoid global catastrophe after 2030. The warning and practical recommendations are based on certain implicit presuppositions of the deeper and long-term developmental tendencies of societies and the whole of human civilization which have to be analysed in order to really understand the problem and its (im)possible solution. I will try to introduce the topic of social and environmental conflicts and their possible resolution through sustainable approaches, first, by articulating the main ideas of the problematic historical dialectic of Western civilization, second, of the

\footnotetext{
1 "A number of climate change impacts that could be avoided by limiting global warming to $1.5^{\circ} \mathrm{C}$ compared to $2^{\circ} \mathrm{C}$, or more. For instance, by 2100 , global sea level rise would be $10 \mathrm{~cm}$ lower with global warming of $1.5^{\circ} \mathrm{C}$ compared with $2^{\circ} \mathrm{C}$. The likelihood of an Arctic Ocean free of sea ice in summer would be once per century with global warming of $1.5^{\circ} \mathrm{C}$, compared with at least once per decade with $2^{\circ} \mathrm{C}$. Coral reefs would decline by $70-90$ percent with global warming of $1.5^{\circ} \mathrm{C}$, whereas virtually all (>99 percent) would be lost with $2^{\circ} \mathrm{C}$ " (IPCC, 2018).
} 
whole of human civilization as well, and, third, a necessary transition from a monological paradigm to an intersubjective paradigm of relations among human beings and the nature in order to overcome the problematic dialectic of the global capitalism and the civilization in general. I will focus on the paradigmatic text of this kind of thinking concerning the repression of nature and conflicts which follow that repression. Even if the text on the dialectic of enlightenment has its own circumscriptions given the fact of its origin being connected to WWII, it deserves attention because it identifies long-term pathological tendencies and, at the same time, paradoxically, it is part of these tendencies due to its lack of ability to overcome the boundaries of the given paradigm. However, its sceptical explanatory critique can be the first move to contributing to founding positive alarmism concerning the contemporary desperate situation which, then, can be reformulated and developed by more developed and sophisticated contemporary analyses. Thus, the argument is broader than a Critical Theory and can address more readers.

\section{Dialectic of Western civilization}

The opening of the theme of a dialectic of civilization is well expressed by Claude Levi-Strauss's (2012 [1955], p. 24) metaphor that our civilization is not any longer the "fragile flower" which must be protected in a cultivated park against surrounding threats. Civilization is created in mass production, in monoculture. The idea draws attention to the expansion of civilization and loss of its need for this kind of protection as it has gained strength. Lévi Strauss's idea can still be considered relatively optimistic, as it only points to excessive civilizational productivism and the planetary push of civilization. This thesis is the starting point, which Theodor Adorno and Max Horkheimer enriched by their explanatory criticism of this civilizational process.

The fact of the brutal destruction produced by the World War II led Adorno and Horkheimer, especially in their joint work Dialectic of Enlightenment (2007), to the ever-increasing rejection of the described development of destructive rationalization and technology and, particularly, to criticism of repression and cultural manipulation. ${ }^{2}$ Settlement of the totalitarian system of dominance was considered the outcome of the erroneous social development since the beginning, as a consequence of expansive rationalization and related technological pathologies from the birth of our civilization to the present. They

\footnotetext{
${ }^{2}$ This kind of critical thinking appeared already in the last year of Studies in Philosophy and Social Science, which was originally a journal of Adorno and Horkheimer's Institute für Sozialforschung in Frankfurt (Horkheimer, 1941, p. 365; comp. Horkheimer, 1941, p. 266-388; Adorno, 1941).
} 
focus on the overwhelmingly negative aspects of this enforcement of civilization against human beings and nature at the very beginning when the process was not over-exacerbated. It is a refusal of civilization.

This pervasive negativism, however, leads to hopelessness. In their pessimistic view, at least an attempt to reverse this pathological development could be considered. However, a reader who does not accept their perspective can at least appreciate and follow the inspirational concept of social critique they have drawn up. Their analysis can be read as an important critical memento that is behind our everyday experience and critical approach. The picture of the negative civilizational tendencies mapped by Horkheimer and Adorno can create the background to a more subtle social criticism. It could be - but was not - supplemented by fundamental reflections on potential social and environmental transformation.

The consequences of technological reasoning, which has had a strong impact on our lives especially since the beginning of modern times, are a challenge that cannot be ignored and overcome. Adorno and Horkheimer's attention is focused on the long-term historical causes of the development of capitalism. They focus primarily on a general critique of Western civilization in relation to the determining role of the negative aspects of rationality. Their interpretation sees the source of pathological civilizational development from antiquity to the present in the negative moments of the rational use of natural processes. This kind of disposition is instrumental to the control of nature, and consequently to the formation of the "relations of social domination".

As stated by Karl Marx (1967 [1867], p. 505-507):

Capitalism production [...] disturbs the metabolic interaction between man and the earth, i.e. prevents the return to the soil of its constituent elements consumed by man in the form of food and clothing; it therefore violates the conditions necessary to lasting fertility of the soil [...] Capitalist production, therefore, develops technology $[\ldots]$ only by sapping the original sources of all wealth - the soil and the worker.

Both authors follow Marx by reinterpreting and extending their critique from the point of view of civilization. They criticize the extensive use of reason; with its roots not only in the 18th century as is usually analysed, but also already in antiquity. From this perspective, their broad concept of the Enlightenment accompanies the whole history of the West. Endeavours to survive and deal with the traps of nature have led to the instrumentalization of human reason since the beginning of Western civilization. As a result of this approach and the formation of the contrast between nature and culture, 
there were three types of nature control and reification. First, the control of external nature, i.e. surrounding nature, in which one lives; the outer world which surrounds us. Second, the control of inner nature, i.e. the life instinct, the nature of human beings. Thirdly, in connection with the second kind of control, not only control of himself or herself but also control of one another.

When Horkheimer and Adorno explain the problem of instrumental reason by finding it already in the canonical texts of Western civilization, in Homer, they show that the development of instrumental reason - from then to the present - has mainly negative aspects. The basis of the developmental dialectic of the formation of Western civilization is the denial of nature and the spreading of a kind of rationality, which is in fact, irrationality. This is a paradox because outer nature began to be dominated through the liberation of human beings who are disciplined and enslaved. There is an expansion of technical rationality and its self-serving development when it forgets its own mediating role, and suppresses the original purpose it should serve. Its development paradoxically becomes a brake on the development of the human being and his surroundings and leads to crises. This evolutionary dialectic has become over time the dialectic of capitalism, a fact with long-lasting historical implications. The economic crisis before World War II and subsequent Nazism and Fascism are just the culmination of this long-term development, which from the beginning of human development has included the transformation of means into purpose.

The essay on Homer's Odyssey (1999) provides an outline of the origins of the development of pathological and crisis features of human reason. Odysseus, the subject here endowed with instrumental rationality, attempts to control the environmental nature around him, his own nature, and the nature of his subordinates. Odysseus is a stray entity who controls in order to strengthen and save his own life but, through this control, he also weakens life. After the war in Troy, he cannot find his way home; he wanders, facing ups and downs, and developing technical rationality as a means for his survival and consumption. What he did not dare at home in a community of loved ones, he takes the liberty to undertake on the road in a situation of isolation, promoting his own ruthless "atomistic interest". Being outside the community of his loved ones enables him to promote dictate in a competitive struggle with others. His approach to life later becomes an exemplary model of the modern Western economy, a technical irrationality that prevents people from meeting their real needs. Economic crises, mass manipulation, concentration camps, and the Holocaust are all results of an overturned technical rationality in modern times. All these manifestations of human dominance have their determining source in 
the spontaneous development of technical rationality since the beginnings of human civilization. The subject of instrumental reason is a subject that evolves in human history from slavery to entrepreneur and administrator.

Homer's Odyssey has an important resemblance to the classical parts of Western civilization, such as Hegel's Phenomenology of Spirit (2018 [1806]) and Marx's Capital (1967 [1867]). In constructing their work, both these authors come from a certain intellectual motif shared in historical culture, from the odyssey. The fascination at that time can be observed in overseas trips of discovery - in fact, of conquest - to the Americas, Africa, and Asia. As Lévi-Strauss states, they, in fact, did not consider their journey the discovery of a new world, they were convinced they had re-found the paradise described in the Bible. In the contemporary global era, it is revived by tourist travel in a simplified commercial way.

The idea of the odyssey which was revived in the philosophical, scientific and literary works of the modern era (Kosik, 2012), consisted in the wandering of a subject in the world, in the knowledge of the world which the subject acquires for himself. ${ }^{3}$ The subject can be an individual human being, a spirit, a collective in the form of a social class, etc. However, it is always true that the subject can only know himself through his own activity, the transformation of the world and hence of himself. The subject changes the world and transforms himself. Goethe's educational novel Wilhelm Meister (2013) or Rousseau's Emil or on Education (1979) are just other versions of Homer's Odyssey, Hegel's Phenomenology of Spirit, or Marx's Capital. All these works are a kind of odyssey. Hegel's odyssey of the spirit is the way in which consciousness in history passes through many forms to know what it is in itself and to become for itself. This historical "experience of consciousness" has its parallel in Marx's Capital, which is the odyssey of specific historical practice. It is a means whereby concrete practice goes from its basic labour product through various forms of practice to a fundamental practical act based on the knowledge and transformation of oneself and of one's surroundings. Today, corporations following their profit rationality create consumerists by pushing them into a journey of permanent economic growth and consumption, at social and environmental costs.

\section{Dialectic of human civilization}

Although Horkheimer and Adorno's interpretation had the ambition to express their opinion on the development of the entire human civilization, it

\footnotetext{
3 "Himself" because this kind of subject was usually considered man at that time; it marginalized and repressed women.
} 
followed almost exclusively criticism of Western culture. However, following Horkheimer and Adorno's logic, it would be necessary to realize that even other cultures are not automatically seamless (Eisenstadt, 2002; Benjamin, 1973). Firstly, non-Western cultures have been hit by Western instrumental rationality during colonialism, the Cold War, and the current global capitalism. Second, even if western cultures were not affected by western influences, we can identify characteristics of human cultures shared by various cultures, including development and expansion that determines instrumental rationality. Western culture should, therefore, remain a center for criticism but other cultures cannot be omitted. We should seriously criticize instrumental reason, not only to focus on the beginnings of western civilization but also on the beginnings of other civilizations in order to see problems in multiple modernities. Alternatives to the European Odyssey are the epics of Ramayana and Mahabharata on the territory of modern-day India, The Epic of Gilgamesh or the Old Testament in the Middle East, for example, if we follow only some paradigmatic classic texts.

In all these works, the ways of searching and wandering are illustrated, as evidenced by the historical process of cultivation on the one hand and the historical process of escalation of instrumental control of people and nature on the other. The idea of a journey presents the subject's path to the world, both literally and metaphorically. Individual and collective subjects are recognized and matured through their deeds which change the world and themselves, i.e. external nature and internal nature. In this process, the subject changes the world, but through instrumental rationality, that develops various forms of control of people and nature. However, it is necessary to point out that the interpretation is based on the illumination of the actions of the individual actors, the heroes of the epics, but the behaviour of the individual subject is only a substitute, and represents the collective process of the development of whole cultures or of the whole of human civilization.

Following this analysis, we can say that the problem of instrumental rationality comes from the beginning of human history, not only in repressive systems but often also implicitly reproduced in opposition to those repressive systems. It existed both in capitalism and in attempts to overcome it, as experienced in the former Eastern Bloc countries. As for environmental issues, we know that also really existing socialism in Central Europe until 1989 and in the Soviet Union until 1991 damaged the environment. Thus, the problem is deeper than capitalism due to the long-term historical evolutionary tendencies of instrumental reason within human civilization. However, because we live in global capitalism now, we have to face the systemic and structural problems mainly in connection to capitalism today. 
Today corporate owners and managers within the system of global capitalism transform Western citizens into consumers, people in peripheral developing countries into producers or a useless reserve army of unemployment, and nature into the sources for production lines. It leads not only to global social pathologies and injustices but also to the destructive consequences of global climate change (Camana and Almeida, 2019).

Due to the fact that the various components of human civilization come into contact with each other in the present global era, and the development of human civilization is indeed becoming a full-planetary one, the hypertrophy of the pathological aspects of instrumental rationality can cause the collapse of human civilization. For this reason, the dangers of global technological development need to be seen as a powerful motive for further analysis, which may seem more promising, but their being anchored in the pathologies of technological development remains a warning.

\section{Positive alarmism: towards global inter-subjective relations between human beings and the nature}

Martin Jay, in his classic book on the history of Critical Theory (1996 [1973]), considered the 1930s and 1940s the most fruitful decade of the Institute for Social Research. Today, however, we know already that Critical theory in those years, especially the essay on the Dialectic of Enlightenment, was strong in its theoretical agenda setting and its focus on critique but there was no, or at best, only a very weak proposal as to what to do. Apart from critique, explanation was only partly developed, and normativity was covered only implicitly and marginally. Considering the Dialectic of enlightenment (2007) in this methodological way, it included a reductive subject-object paradigm that did not allow for (1) a sufficient explanation of the reality and (2) a developed normativity. Instrumental reason as a mono-logical approach of man to other human beings and to nature is based on subjectobject relations. These relations were an adequate target of critique yet did not permit the description of the inter-subjective (specifically communicative and social) dimensions of human life and its relation to nature, and to develop a normative proposal for an inter-subjective approach to pathologies and injustices.

It was not an adequate description of historical development with various deviations from such a description in the past and future possibilities. It is important to distinguish between an unnecessarily generalizing refusal of rationality as such and a required critique of the domination of technological or instrumental reason (Habermas, 2015; Honneth, 2000). Thus, the Enlightenment 
critique is problematic as a critical description and descriptive critique because it offers only a vague perspective.

And it is also not adequate as a normative point of view. The position is one-sided and inappropriate because it does not describe the normative possibility of crossing the given state. There is no room for at least partial free action against the negative tendencies of instrumental rationality in historical development. The highly sceptical, almost fatalistic, the position does not include such a possibility of critical correction.

There can at least be attempts to overcome one-sided use and misuse of instrumental rationality. Instrumental rationality can be used positively yet it should not be the main principle of action. Otherwise, it becomes a problematic assumption on which authoritarian non-participatory systems can be established. A redefinition of the position can be achieved by refusing resignation and attempting to carry out meaningful activities that would allow inter-subjective development by cultivating patterns of mutual relations among people (Honneth, 2011), and also between people and nature, even if still against a background of pathological technological development, which in the 20th century resulted in the civilizational regression of two world wars, and continues to threaten humanity and the environment through planetary homogenisation, supranational authoritarian tendencies, and a world war (Hrubec, 2016).

The analysis has to include systemic and structural parts and parts dealing with subjects as well. However, if we were to take only the general subject of humanity, we would miss the specific subject groups which are mainly responsible for problems and also those who resist. In looking for positive fragments of society's development, it leads us to the question related to the Dialectic of Enlightenment of whether it is most appropriate to analyse only the characteristics of Odysseus. Additional interpretations require critical points of view of the people who were subordinate to Odysseus: his subordinate men who did not have the lead word in decision-making, as well as women and other subordinate subjects, including slaves (Atwood, 2005; see Jaggar, 2005).

Today in the era of global capitalism (Sklair, 2016; Robinson, 2014; Harris, 2016), we have to identify the systemic and structural problems and the specific subjects as well. I have already indicated that today's corporation owners and interlinked politicians, managers, and technicians follow the profit rationality, and create consumers by pushing them into permanent economic growth and meaningless mass consumption, at heavy social and environmental costs mainly in developing countries. Consumerists are willing to go this way; 
having their own part of the responsibility for the negative consequences of this lifestyle too even if they still do not admit it. However, we have also to take into account that long-term historical technological development linked to the expansion of instrumental rationality is not directly and consciously shaped by individual agents and that individual possibilities for its correction are very difficult. Action has to be a long-term inter-subjective activity, which would include individual and collective agents as well.

\section{Conclusion}

The topic of this special journal issue is analysed from several important thematic aspects and territorial perspectives. While authors of papers are from the Czech Republic, the Slovak Republic, Brazil, Great Britain, and the USA, they cover a broader territorial scope in their analyses than the countries of their origin. They analyse social and environmental conflicts mainly in four territorial areas: in the West, India, China, and Africa. At the same time, several of them explain the relations between social and environmental risks and threats on the global level as well. Leslie Sklair focuses on a concept of the Anthropocene which allows for an explanation that human beings are the main forces shaping the planet Earth today. The Anthropocene can be reformulated mainly as the Capitalocene in the contemporary stage of global development, stressing the role of capitalism, but not exclusively. Oleg Suša and Richard St'ahel focus on the global dynamics of the accumulated problems of socio-environmental dangers which block the way to a real sustainable development with social and environmental justice. They mainly stress global climate change and related ecological and socio-economic problems, including migration, hunger, poverty, social inequalities, exploitation, accumulation by dispossession, and the proliferation of warfare. Ângela Camana and Jalcione Almeida deal with the unsustainability of misused concept development linked to construction of new territories based on a repressive idea of emptiness, i.e. on an idea of disarticulation and destruction of traditional territories of indigenous peoples. By this process, transnational corporations and affiliated governments produce an administrative and mass media construction of depopulation, conflicts, and marginalization of indigenous groups in order to get profits in agro-business, for example in Africa. The most developed countries (the USA and EU), due to their large consumption, the most populous countries (China and India), and also countries with destruction of tropical rain forests (mainly Brazil, Congo, Indonesia), are the most problematic macro-regions of the world concerning environment even if they are already taking some limited specific ecological measures. In this context, Jiří Krejčík 
addresses the threats and contradictions of conservative Hindu trends in the Indian environmental context, while, on the contrary, Jerry Harris raises the question of whether China as a specific model can bring about hope after decades of massive pollution and with the new ecological attempts to improve environment now, i.e. if China's project of green socialism can transform contemporary global capitalism in future. We will see if the EU countries and China will be really leaders in developing ecological civilization (Pan, 2016; Yang and Jiang, 2018).

Josef Šmajs, in a more practical manner, yet based deeply on a theoretical perspective of evolutionary ontology, analyses two major transformations of human beings: first, a self-preservation modification of modern humans, and second, a mental separation from nature before the end of the Neolithic culture. It has led to a step-by-step alienation of humans from nature over history. This is why he makes a normative proposal to pursue a biophile transformation of human culture, human civilization. It means a transition from an unsustainable predatory paradigm to a sustainable biophile paradigm.

To conclude, the analysis of serious pathologies and injustices of our civilization in connection to the United Nations ecological proposals can be considered a relevant critical memento in the contemporary environmental crisis, similar to the critical memento during the WWII when the text on the dialectic of enlightenment was written. It is a positive alarmism, which can wake up hitherto passive subjects of positive change. Of course, simpleminded alarmism in the shallow form of business, as usual, is not an adequate approach. However, sophisticated and deeply based positive alarmism can be an appropriate approach because people have, so far, not reacted to the contemporary social and environmental conflicts in an adequate manner over recent decades. Thus, it is necessary to choose a different approach. Positive alarmism can be the first step towards deeper and complex critical, explanatory, and normative analyses leading to the practice of inter-subjective relations among human beings, and between human beings and nature which would be based on non-pathological, just and ecological sustainable approaches from local to global levels (see Löwy, 2015; Williams, 2010).

Of course, sceptics may say that positive alarmism is unlikely to work, just as the milder information campaigns in previous decades have not worked. If that were true, George Monbiot's scenario, who says a people's rebellion is the only way to fight climate breakdown (Monbiot, 2018), could be considered. If this scenario were not successful as well, there would not be long to wait for a collapse. Then, there is only the hope that the catastrophe will not be too big that it cannot be fixed in the future. 


\section{Acknowledgements}

I would like to thank all the authors of the articles in this special issue for their cooperation. Marek Hrubec, Oleg Suša and Jiří Krejčík's research was made in the framework of the research programme "Global Conflicts and Local Interactions", Strategy AV21, The Czech Academy of Sciences. You can compare this special issue of Civitas journal with our thematic symposium in Critical Sociology journal (New York) which addresses three dimensions of the research program: militarized escalation; transnational societal contradictions; ambivalences of civil society in the West and in Africa <www.researchgate. net/publication/328003196_Global_Conflicts_and_Local_Interactions_ Contradictions_of_Global_Capitalism_and_Civil_Society>.

\section{References}

ADORNO, Theodor W. Veblen's attack on culture. Studies in Philosophy and Social Science, v. 9, p. 389-413, 1941.

ADORNO, Theodor W.; HORKHEIMER, Max. Dialectic of Enlightenment. Stanford University Press 2007.

ATWOOD, Margaret. The Penelopiad. New York: Knopf, 2005.

BENJAMIN, Nelson. Civilizational complexes and intercivilizational encounters. Sociological Analysis, v. 34, n. 2, p. 79-105, 1973. https://doi.org/10.2307/3709717

CAMANA, Ângela; ALMEIDA, Jalcione. Da insustentabilidade do desenvolvimento. Os discursos da produção de "vazios" no âmbito de um programa de cooperação internacional. Civitas, Porto Alegre, v. 19, n. 2, p. 391-408, 2019. https://doi.org/ 10.15448/1984-7289.2019.2.32057

EISENSTADT, Shmuel N. (ed.). Multiple modernities. New Brunswick: Transactions Publishers, 2002.

GOETHE, Johann Wolfang von. Wilhelm Meister's apprenticeship: a novel. Indore: Kartindo Publishing House, 2013.

HABERMAS, Jürgen. The theory of communicative action. Vol. 1, Cambridge: Polity, 2015.

HARRIS, Jerry. Global capitalism and the crisis of democracy. Atlanta: Clarity Press, 2016.

HEGEL, Georg W. F. Phenomenology of Spirit. Cambridge: Cambridge University Press, 2018.

HOMER. Oddysey. London: Penguin Classics 1999. 
HONNETH, Axel. The possibility of a disclosing critique of Society: the Dialectic of Enlightenment in light of current debates in social criticism. Constellations, v. 7, n. 1, p. 116-127, 2000. https://doi.org/10.1111/1467-8675.00173

HONNETH, Axel. Das Recht der Freiheit. Grundriß einer demokratischen Sittlichkeit. Berlin: Suhrkamp, 2011. https://doi.org/10.1163/15700739-90000013

HONNETH, Axel. Das Recht der Freiheit. Grundriß einer demokratischen Sittlichkeit. Berlin: Suhrkamp, 2011. https://doi.org/10.1163/15700739-90000013

HORKHEIMER, Max. Foreword. Studies in Philosophy and Social Science, New York, v. 9, n. 3, p. 321, 1941.

HORKHEIMER, Max. The end of reason. Studies in Philosophy and Social Science, New York, v. 9, p. 316-389, 1941.

HRUBEC, Marek. Conflicts of the global state. International Critical Thought, v. 6, n. 3, p. 378-392, 2016. https://doi.org/10.1080/21598282.2016.1198002

INTERGOVERNMENTAL Panel. Climate Change Press Release. Geneva, 2018. Available: https://www.ipcc.ch/site/assets/uploads/2018/11/pr_181008_P48_spm_ en.pdf. 11 Nov. 2018

JAGGAR, Alison M. "Saving Amina": Global justice for women and intercultural dialogue. Ethics and International Affairs, v. 19, n. 3, p. 55-75, 2005. https://doi. org/10.1111/j.1747-7093.2005.tb00554.x

JAY, Martin. The dialectical imagination. California: University of California, 1996.

KOSIK, Karel. Dialectics of the concrete. A study on problems of man and world. Berlin: Springer, 2012.

LAMBERTINI, Marco. A new global deal for nature and people urgently needed. In: Monique, Grooten; Rosamunde, Almond, R. E. A (org.). WWF 2018. Living Planet Report-2018: Aiming Higher. Gland: WWF, 2018. Available: http://awsassets.panda. org/downloads/_embargo_30_oct_lpr2018_full_report_spreads_25_10_2018.pdf. 5 Nov. 2018.

LEVI-STRAUSS, Claude. Tristes tropiques. London: Penguin Classics, 2012.

LÖWY, Michael. Ecosocialism. Chicago: Haymarket Books, 2015.

MARX, Karl. Capital. Vol. 1, New York: International Publishers, 1967.

MEADOWS, Donella H.; MEADOWS, Dennis L.; RANDERS, Jorgen; BEHRENS, William W. The limits to growth. A report for the club of Rome's project on the predicament of mankind. New York: Universe Books, 1972. https://doi.org/ 10.1349/ddlp. 1 
MONBIOT, George. As the fracking protesters show, a people's rebellion is the only way to fight climate breakdown. The Guardian, 2018. Available: www.theguardian. $\mathrm{com} / \mathrm{commentisfree/2018/oct/18/governments-no-longer-trusted-climate-change-}$ citizens-revolt. 20 Oct. 2018.

PAN, Jiahua. China's environmental governing and ecological civilization. Berlin: Springer, 2016.

ROBINSON, William. Global capitalism and the crisis of humanity. New York: Cambridge University Press, 2014.

ROUSSEAU, Jean-Jaques. Emile or on education. New York: Perseus Books, 1979.

SKLAIR, Leslie. The transnational capitalist class, social movements, and alternatives to capitalist globalization. International Critical Thought v. 6, n. 3, p. 329-341, 2016. https://doi.org/10.1080/21598282.2016.1197997

THEPARISAgreement.UNClimateChange,2015.Available:https://unfccc.int/processand-meetings/the-paris-agreement/the-paris-agreement. https://doi.org/10.1163/ 9789004322714 cclc 2015-0176-001

UNITED Nations. The Paris agreement. Climate change. Paris: United Nations, 2015. Available: https://unfccc.int/process-and-meetings/the-paris-agreement/the-parisagreement. 22 Oct. 2018. https://doi.org/10.18356/f3f6b94d-en

UNITED Nations. Transforming our world: the 2030 Agenda for sustainable development. Sustainable Development. New York: United Nations, 2012. Available: https://sustainabledevelopment.un.org/content/documents/21252030\%20Agenda \%20for\%20Sustainable\%20Development\%20web.pdf. 12 Nov. 2012. https://doi.org/ $10.18356 /$ e5a72957-en

WILLIAMS, Chris. Ecology and Socialism. Chicago: Haymarket Books, 2010.

YANG, Xiaojun; JIANG, Shijun (ed.). Challenges towards ecological sustainability in China: An Interdisciplinary Perspective. Berlin: Springer, 2018.

Received at: 15 Jan. 2019

Aproved at: 21 Jan. 2019

Published at: 30 July 2019

Corresponding author:

Marek Hrubec

Jilská 1

11000 Prague 1 - Czech Republic

MAReK HRUBEC < hrubec@flu.cas.cz>

PhD., Institute of Philosophy of the Czech Academy of Sciences, Prague, Czech Republic.

Orcid: https://orcid.org/0000-0001-9498-8678 